\title{
PREDIKSI DAN ANALISIS TEMPAT PEMBUANGAN AKHIR (TPA) SAMPAH DI KOTA PADANG
}

\author{
Mia Audina \\ Program Studi Geografi, \\ Fakultas Ilmu Sosial, Universitas Negeri Padang \\ Email: miaaudina0406@gmail.com
}

\begin{abstract}
Abstrak
Penelitian ini bertujuan untuk1) mengetahui tutupan lahan Kota Padang, 2) mengetahui prediksi jumlah penduduk dan volume sampah di Kota Padang 3) mengetahui luas TPA dan lokasi rekomendasi TPA.

Metode yang digunakan dalam penelitian ini adalah metode analisis kuantitatif. Model yang digunakan Sistem Informasi Geografis (SIG) di overlay menggunakan parameter pengharkatan.

Hasil penelitian menunjukkan, 1) analisis tutupan lahan Citra Landsat Kota Padang tahun 2016 adalah; Vegetasi (51486,40 Ha), Lahan Terbangun (11578,44 Ha), dan Sawah (5713,93 Ha). 2) prediksi penduduk pada tahun 2026 sebesar 1.011.166 jiwa dan prediksi volume sampah sebesar 2.952.604.720 kg/jiwa,.3) lahan yang dibutuhkan untuk TPA sebesar 45,67 Ha dengan luas daerah penyangga 11,42 Ha. Rekomendasi pendirian TPA berada pada Kecamatan Koto Tangah dan Kuranji.
\end{abstract}

Kata kunci:Tutupan Lahan, Kepadatan Penduduk dan Volume Sampah, Luas TPA dan Rekomendasi TPA

\section{Abstract}

This study aims to 1) to know the land cover of Padang City, 2) to know the prediction of population and the volume of waste in Padang City 3) to know the extent of TPA and the location of the TPA recommendation.

The method used in this research is quantitative analysis method. The model used Geographic Information System (GIS) in overlay using the parameters.

The results showed, 1) analysis of land cover Citra Landsat Padang in 2016 is; Vegetation (51486,40 Ha), Built Land (11578.44 Ha), and Rice Field (5713,93 Ha). 2) population prediction in 2026 of 1,021,329 people and prediction of waste volume of $2.952 .604 .720 \mathrm{~kg} / \mathrm{soul}$. $3)$ the land needed for the landfill of $45.67 \mathrm{Ha}$ with a buffer area of 11.42 Ha. The recommendations for the establishment of TPA are located in Koto Tangah and Kuranji Subdistricts.

Keywords:Land Cover, Population Density and Waste Volume, Extensive Landfill and Landfill Recomendation 


\section{PENDAHULUAN}

Sampah merupakan suatu masalah yang perlu diperhatikan. Sampah jika tidak diperhatikan dengan baik akan menga kibatkan permasalahan lingkungan seperti masalah kesehatan, kenyamanan, ketertiban, dan keindahan. Untuk mencapai kondisi masyarakat yang hidup sehat dan sejahtera di masa yang akan datang, sangat diperlukan adanya lingkungan permukiman yang sehat. Dari aspek persampahan, maka kata sehat akan berarti sebagai kondisi yang dapat dicapai bila sampah dapat dikelola secara baik sehingga tercipta lingkungan permukiman yang bersih.

Persoalan lingkungan yang selalu menjadi isu besar di hampir seluruh wilayah perkotaan adalah masalah sampah. Laju pertumbuhan ekonomi di kota dimungkinkan menjadi daya tarik luar biasa bagi penduduk untuk hijrah ke kota (urbanisasi), sehingga terjadi tekanan penduduk di wilayah perkotaan. Akibat dari tekanan penuduk tersebut menyebabkan alih fungsi lahan di daerah perkotaan yang secara umumnya dari lahan pertanian ke non pertanian.

Tingginya kepadatan penduduk membuat konsumsi masyarakat pun semakin tinggi, hal ini menjadi persoalan sampah di perkotaan yang tak kunjung selesai. Di sisi lain lahan untuk menampung sisa konsumsi terbatas. Persoalan semakin bertambah ketika sampah - sampah konsumsi warga perkotaan banyak yang tidak mudah terurai, terutama plastik. Semakin menumpuknya sampah plastik akan menimbulkan pencemaran serius. Hasil riset Jenna.R.Jambeck dan kawan-kawan dalam (Sari, 2017) pada tahun 2015 Indonesia berada di posisi kedua penyumbang sampah plastik ke laut setelah Tiongkok, disusul Filipina, Vietnam, dan Sri Lanka.

Timbulan sampah dapat menyebabkan berbagai permasalahan baik langsung maupun tidak langsung bagi penduduk kota terutama daerah di sekitar tempat penumpukan. Dampak langsung dari penanganan sampah yang kurang bijaksana diantaranya adalah berbagai penyakit menular maupun penyakit kulit, gangguan pernafasan serta dapat mengganggu kesehatan manusia dan mengganggu estetika lingkungan, karena terkontaminasi pemandangan oleh tumpukan sampah dan bau busuk yang menyengat hidung, sedangkan dampak tidak langsung diantaranya adalah bahaya banjir yang disebabkan oleh terhambatnya arus air di sungai karena terhalang timbunan sampah yang dibuang ke sungai.

Permasalahan tentang sampah sudah sangat sering terjadi di perkotaan. Pengelolaan sampah yang kurang baik dan terbatasnya tempat pembuangan sampah menjadi salah satu faktor penyebabnya. Semakin bertambahnya jumlah penduduk 
yang tidak diimbangi dengan pengelolaan tempat pembuangan sampah yang baik akan menyebabkan masalah lingkungan. Dengan adanya penambahan jumlah sampah menyebabkan TPA yang ada akan semakin penuh sehingga membutuhkan lokasi baru.

Perkiraan-perkiraan dampak penting suatu lokasi TPA yang berpengaruh kepada masyarakat saat operasi maupun sesudah beroperasi harus sudah dapat diduga sebelumnya. Pendugaan dampak ini, diantaranya berkaitan dengan penerapan kriteria pemilihan lokasi TPA sampah. Kriteria pemilihan lokasi TPA sampah di Indonesia telah diatur dalam Surat Keputusan Standar Nasional Indonesia (SK SNI) T-11-1991-03 yang tertuang dalam Keputusan Direktorat Jenderal Cipta Karya No: 07/KPTS/CK/1999.

Kota Padang merupakan salah satu kota di Indonesia yang menghasilkan sampam \pm 666 Ton/ hari dikutip dari website dkp Kota Padang. pengelolaan sampah yang ada di Kota Padang melibatkan empat dinas, yaitu Dinas Kebersihan dan Pertamanan, Dinas Pasar, Dinas Pariwisata, dan Dinas Pekerjaan Umum. TPA Air Dingin merupakan satu - satunya TPA di Kota Padang yang terletak di Kelurahan Air Dingin dan Kelurahan Baringin Kecamatan Koto Tangah Kota Padang, dan dikelola oleh Dinas Kebersihan dan Pertamanan (DKP) Kota Padang.
Kemampuan Tempat Pembuangan Akhir (TPA) di Air Dingin dalam menampung sampah di Kota Padang hanya tinggal 8 tahun lagi. Hal ini disampaikan Kepala Bapedalda Kota Padang, Edy Harsyimi, (dikutip tanggal 07 April 2016 jam 17:14:38 WIB, dari KATASUMBAR.com).

TPAS Air Dingin ini mempunyai luas lahan sebesar $33 \mathrm{Ha}$ dan mulai dioperasikan semenjak tahun 1989 dengan system pengoperasian open dumping. Pada tahun 1993 pengoperasian yang dilakukan berubah yaitu menerapkan system sanitary landfill. Sistem sanitary landfill ini direncanakan akan beroperasi sampai dengan tahun 2015.

Namun pada kenyataannya hingga saat ini TPA Air Dingin di Kota Padang masih melakukan pengolahan secara open dumping, dengan lahan yang telah dioperasikan sekitar 50\% dari luas lahan yang ada. Mahalnya biaya operasional adalah salah satu alasan system sanitary landfill tidak bisa dilakukan oleh Pemda Kota Padang. Dalam RUTRK (Rencana Umum Tata Ruang Kota) tahun 1990 - 2003 berdasarkan Perda No. 10 tahun 1993, lokasi TPA Air Dingin telah dicantumkan dan sesuai dengan peruntukkannya. Lokasi TPA ini sebagian besar dikelilingi oleh deretan Bukit Barisan.

Tempat pembuangan sampah yang dibutuhkan adalah tempat 
pembuangan yang memenuhi standar kelayakan sehingga tidak menyebabkan masalah lingkungan. Namun dalam kenyataannya, penyediaan tempat pembuangan sampah ini terhambat oleh ketersediaan lahan. Apalagi di daerah perkotaan yang ketersediaan lahan terbukanya sudah sangat sedikit. Dengan demikian diperlukan adanya studi kelayakan untuk menentukan lokasi tempat pembuangan sampah yang sesuai dengan standar yang ada.

Bertitik tolak dari berbagai masalah yang telah diungkapkan diatas maka, manarik minat penulis untuk studi kelayakan penentukan lokasi tempat pembuangan sampah yang sesuai dengan SNI di Kota Padang, yang diwujudkan dalam sebuah penelitian yaitu "Prediksi dan Analisis Tempat Pembuangan Akhir (TPA) Sampah di Kota Padang”

\section{KAJIAN TEORI}

A. Sampah

Menurut definisi World Health Organization (WHO) sampah adalah sesuatu yang tidak digunakan, tidak dipakai, tidak disenangi atau sesuatu yang dibuang yang berasal dari kegiatan manusia dan tidak terjadi dengan sendirinya (Chandra, 2006). Undang-Undang Pengelolaan Sampah Nomor 18 tahun 2008 menyatakan sampah adalah sisa kegiatan seharihari manusia dan/atau dari proses alam yang berbentuk padat.
B. Tutupan Lahan

Menurut Luncapis (2004) deteksi perubahan fitur permukaan bumi dalam suatu periode waktu merupakan hal penting untuk memahami hubungan antara manusia dan fenomena alam, yang berkaitan dengan menyusun keputusan pengelolaan dan penggunaan sumber daya alam.

C. Proyeksi Penduduk

Proyeksi penduduk (population projections) dan peramalan penduduk (population forecast) sering dipergunakan sebagai dua istilah yang sering dipertukarkan. Meskipun demikian, kedua istilah ini sebenarnya memiliki perbedaan yang sangat mendasar. Berbagai literatur menyatakan proyeksi penduduk sebagai prediksi atau ramalan yang didasarkan pada asumsi rasional tertentu yang dibangun untuk kecenderungan masa yang akan datang dengan menggunakan peralatan statistik atau perhitungan matematik. Di sisi lain, peramalan penduduk (population forecast) bisa saja dengan/ tanpa asumsi dan atau kalkulasi tanpa kondisi, syarat dan pendekatan tertentu (Smith, et.al dalam Junaidi, 2017).

D. Timbulan Sampah

Timbulan sampah pada masing - masing kota di Indonesia berbeda tergantung dari kepadatan penduduk dan kategori kota tersebut. Dikutip dari website dinas DKP Kota Padang volume timbulan sampah perorang adalah $0,8 \mathrm{Kg} / \mathrm{o} / \mathrm{hari}$. 
E. Luas Lahan TPA

Lahan diartikan sebagai lingkungan fisik yang terdiri atas iklim, relief, tanah, air, flora dan fauna, serta bentukan hasil budaya manusia. Dalam hal ini lahan juga mengandung pengertian ruang tempat (Arsyad, 1989).

F. Tempat Pembuangan Akhir (TPA) Sampah

Menurut Techobanoglou, 1993 mengatakan pengelolaan sampah adalah suatu bidang yang berhubungan dengan pengaturan terhadap penimbunan, penyimpanan (sementara), pengumpulan, pemindahan dan pengangkutan, pemrosesan dan pembuangan sampah dengan suatu cara yang sesuai dengan prinsip-prinsip terbaik dari kesehatan masyarakat, ekonomi, teknik (engineering), perlindungan alam (conservation), keindahan dan pertimbangan lingkungan lainnya dan juga mempertimbangkan sikap masyarakat.

\section{METODOLOGI PENELITIAN}

Metode yang digunakan dalam penelitian ini adalah metode analisis kuantitatif. Model yang digunakan adalah Sistem Informasi Geografis (SIG) yang digunakan dalam parameter pengharkatan dengan skoring yang kemudian ditumpangsusunkan (overlay). Lokasi penelitian berada di wilayah Kota Padang.

Tabel 1: Metode yang dipaki dalam analisa data

\begin{tabular}{|l|l|l|l|}
\hline No & \multicolumn{1}{|c|}{ Data } & \multicolumn{1}{|c|}{ Metode } & \multicolumn{1}{|c|}{ Hasil } \\
\hline 1. & Tutupan Lahan & $\begin{array}{l}\text { 1. Sistem Informasi } \\
\text { Geografis (SIG) } \\
\text { 2. Microsoft Excel }\end{array}$ & $\begin{array}{l}\text { 1. Untuk menganalisis } \\
\text { tutupan lahan Kota } \\
\text { Padang. } \\
\text { 2. Untuk menentukan luas } \\
\text { tutupan lahan Kota } \\
\text { Padang. }\end{array}$ \\
\hline 2. & $\begin{array}{l}\text { Data jumlah penduduk } \\
\text { Kota Padang tahun } \\
\text { 2006 dan 2016. }\end{array}$ & $\begin{array}{l}\text { Metode proyeksi } \\
\text { penduduk; eksponensial }\end{array}$ & $\begin{array}{l}\text { Prediksi jumlah penduduk } \\
\text { untuk tahun 2026. }\end{array}$ \\
\hline 3. & $\begin{array}{l}\text { Data prediksi jumlah } \\
\text { penduduk } \\
\text { Padang }\end{array}$ & $\begin{array}{l}\text { Hasil analisis timbulan } \\
\text { sampah perorangan } \\
\text { dikalikan prediksi } \\
\text { jumlah penduduk. }\end{array}$ & $\begin{array}{l}\text { Prediksi volume sampah yang } \\
\text { ditimbulkan. }\end{array}$ \\
\hline 4. & $\begin{array}{l}\text { Data prediksi volume } \\
\text { sampah }\end{array}$ & Murtudo (1996), & Luas TPA yang dibutuhkan. \\
\hline
\end{tabular}




\begin{tabular}{|l|l|ll|l|}
\hline 5. & $\begin{array}{l}\text { Peta lereng, geologi, } \\
\text { badan air, penggunaan } \\
\text { lahan, fungsi kawasan, } \\
\text { tanah, hujan, dan pola } \\
\text { ruang Kota Padang. }\end{array}$ & 2. Sistem Informasi & Geografis (SIG) \\
& & & $\begin{array}{l}\text { Menentukan kesesuaian } \\
\text { lahan untuk TPA di Kota } \\
\text { Padang. }\end{array}$ \\
& & $\begin{array}{l}\text { 2. } \begin{array}{l}\text { Menentukan luas lahan } \\
\text { yang cocok untuk di } \\
\text { jadikan TPA. }\end{array} \\
\text { 3enentukan lokasi } \\
\text { rekomendasi untuk TPA. }\end{array}$ \\
\hline
\end{tabular}

\section{HASIL DAN PEMBAHASAN}

A. Tutupan Lahan Kota Padang

Gambaran karakteristik tutupan lahan di Kota Padang diawali dengan melakukan overlay peta batas administrasi wilayah Kota Padang. Tutupan lahan Kota Padang diperoleh dari hasil digitasi Citra Landsat +7TM Kota Padang tahun 2016 dengan melakukan interpretasi visual.

Klasifikasi Citra Landsat +7TM Kota Padang bertujuan untuk pengelompokan atau melakukan segmentasi terhadap kenampakan kenampakan alam dengan menggunakan teknik Sistem
Informasi Geografi. Analisis Citra Landsat +7TM Kota Padang tahun 2016 digolongkan menjadi 3 jenis tutupan lahan yaitu lahan lahan terbangun, sawah, dan vegetasi. Hal tersebut dapat dilihat pada tabel dan dan gambar peta tutupan lahan Kota Padang dibawah ini:

Tabel 14: Tutupan Lahan 2016

\begin{tabular}{|l|l|l|}
\hline Tutupan Lahan & Kode & $\begin{array}{l}\text { Luas } \\
(\mathbf{H a})\end{array}$ \\
\hline Lahan Terbangun & 1 & 11578,44 \\
\hline Sawah & 2 & 5713,93 \\
\hline Vegetasi & 3 & 51486,40 \\
\hline
\end{tabular}

Gambar 1 : Peta Tutupan Lahan Kota Padang Tahun 2016

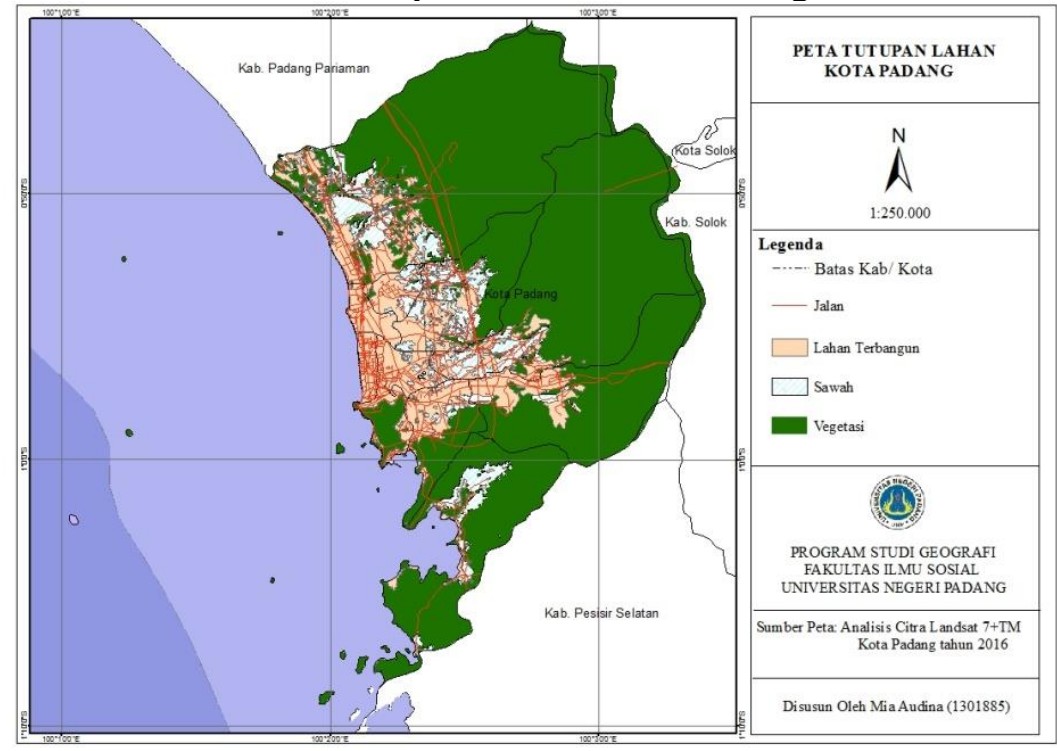

Sumber : Analisis Citra Landsat 7+TM Kota Padang tahun 2016 
Hasil analisis Citra Landsat 7+TM Kota Padang tersebut menghasilkan tutupan lahan di Kota Padang masih didominasi vegetasi. Karena sebagian daerah Kota Padang di lewati oleh bukit barisan dan kontur yang tinggi menyebabkan separuh wilayah Kota Padang berupa hutan yang dilindungi oleh pemerintah. Adapun luas terbesar sampai ke yang terkecil berdasarkan hasil klasifikasi adalah sebagai berikut ; Vegetasi (51486,40 Ha), Lahan Terbangun (11578,44 Ha), dan Sawah (5713,93 Ha).

Tutupan lahan merupakan istilah yang digunakan untuk meyebutkan suatu kenampakan lahan secara fisik, baik kenampakan alami maupun kenampakan buatan manusia. Metode yang digunakan dalam menganalisis tutupan laha di Kota Padang adalah klasifikasi terbimbing. Klasifikasi Terbimbing pencirian spektralnya tidak akan berubah karena adanya pemberian sampel dalam menghasilkan kelas informasi yang mana sampel tersebut ditentukan terlebih dahulu oleh peneliti. Klasifikasi terbimbing sendiri terbagi menjadi beraneka ragam. Salah satu pendekatan yang paling sering digunakan adalah klasifikasi maximum likelihood classification, meskipun ada beberapa kelemahan dari pendekatan ini salah satunya yaitu banyaknya kesalahan klasifikasi yang ditimbulkan oleh salt dan pepper, terutama jika piksel berada di luar area spesifik atau diantara area yang tumpang tindih, yang dipaksakan untuk diklasifikasikan (Rusdi 2005).
B. Laju Pertumbuhan Penduduk di Kota Padang

Berdasarkan data jumlah penduduk Kota Padang yang bersumber dari buku Padang Dalam Angka 2016 diketahui pada tahun 2006 jumlah penduduk Kota Padangsebesar 819.740 jiwa. Kemudian pada tahun 2016 jumlah penduduk Kota Padang menjadi 914.941 jiwa. Dari data jumlah penduduk tersebut dapat dihitung laju pertumbuhan penduduk dengan menggunakan rumus eksponensial sebagai berikut:

$$
\begin{aligned}
& r=\frac{1}{t} \ln \left(\frac{P_{t}}{P_{o}}\right) \\
& r=\frac{1}{10} \operatorname{In}\left(\frac{914.941 \text { jiwa }}{819.740 \text { jiwa }}\right) \\
& r=\frac{1}{10} \operatorname{In} \quad(1,116135604) \\
& r=0,0109872366 \\
& \text { Jangka waktu }=\mathrm{t}_{\text {prediksi }}-\mathrm{t}_{\text {awal }} \\
&= \text { tahun } 2026-\text { tahun } \\
& 2016 \\
&= 10 \text { tahun }
\end{aligned}
$$

Prediksi jumlah penduduk pada tahun 2026:

$P_{t}=P_{o} e^{r t}$

$\mathrm{Pt}=914.941$ jiwa

$\left(2,718281828^{0,01 * 11}\right)$

$\mathrm{Pt}=914.941$ jiwa $(1,1051709181)$

$\mathrm{Pt}=1.011 .166$ jiwa

Dari hasil tersebut dapat diketahui laju pertumbuhan penduduk Kota Padang per tahunnya adalah 0,0109 atau melebihi $1 \%$ dan prediksi jumlah penduduk pada tahun 2026 sebesar 1.011.166 jiwa. Selanjutnya prediksi jumlah penduduk Kota Padang tahun 2026 
dikalkulasikan dengan volume sampah perorangan, dimana volume sampah perorangan Kota Padang sebesar 0,8 kg. Maka laju timbulan sampah masyarakat Kota Padang dari tahun 2016 hingga tahun 2026 sebesar:

Volume sampah

$$
\begin{aligned}
&= 0,8 \mathrm{~kg} \times 365 \text { hari } \\
&= 292 \mathrm{~kg} / \mathrm{o} / \mathrm{t} \times 10 \text { tahun } \\
&= 2.920 \mathrm{~kg} / \mathrm{o} / 10 \mathrm{t} \times 1.011 .166 \\
& \text { jiwa } \\
&= 2.952 .604 .720 \mathrm{~kg} / \text { jiwa } \\
& \text { Dengan asumsi pengoperasian }
\end{aligned}
$$
TPA dimulai pada tahun 2016 maka diperoleh prediksi total sampah Kota Padang sampai tahun 2026 sebesar 2.952.604.720 kg/ jiwa.

Peningkatan jumlah penduduk akan mempengaruhi perilaku/ gaya hidup serta pola konsumsi masyarakat. Perubahan ini akan memengaruhi volume sampah di Kota Padang. Berbagai literatur menyatakan proyeksi penduduk sebagai prediksi atau ramalan yang didasarkan pada asumsi rasional tertentu yang dibangun untuk kecenderungan masa yang akan datang dengan menggunakan peralatan statistik atau perhitungan matematik. Di sisi lain, peramalan penduduk (population forecast) bisa saja dengan/ tanpa asumsi dan atau kalkulasi tanpa kondisi, syarat dan pendekatan tertentu (Smith, et.al dalam Junaidi 2017). Prediksi atau ramalan jumlah penduduk sendiri diperlukan untuk menghitung volume sampah di masa yang akan datang

Dari perhitungan prediksi jumlah penduduk Kota Padang tahun
2006 dan 2016 dapat disimpulkan bahwa laju pertumbuhan penduduk Kota Padang sebesar 0, 0109 atau melebihi $1 \%$ dimana besar dari 0 maka telah terjadi penambahan penduduk dari tahun sebelumnya, dari laju perumbuhan penduduk ini juga dapat diprediksi jumlah penduduk Kota Padang pada tahun 2026 sebesar 1.011.116 jiwa. Sedangakan hasil prediksi volume sampah Kota Padang pada tahun 2026 sebesar $2.952 .604 .720 \mathrm{~kg} /$ jiwa.

C. Luas TPA dan Rekomendasi Lokasi TPA di Kota Padang

Untuk mencari kapasitas luas TPA terlebih dahulu dihitung volume sampah yang telah dipadatkan. Jumlah volume timbulan sampah Kota Padang dari tahun 2016 sampai tahun 2026 (perkiraan perencanaan penggunaan lahan TPA) dengan membagi volume total sampah $(\mathrm{kg})$ dengan kepadatan sampah $(250$ $\mathrm{kg} / \mathrm{m} 3$ ) adalah:

$\mathrm{V}=2.952 .604 .720 \mathrm{~kg} /$ jiwa: 250 $\mathrm{kg} / \mathrm{m}^{3}$

$$
=11.810 .418,88 \mathrm{~m}^{3}
$$

Volume total sampah dikurangi $25 \%$ (aktivitas pemulung) dari total sampah:

$$
\begin{aligned}
& \mathrm{V}_{\mathrm{tt}} \quad=11.810 .418,88 \mathrm{~m}^{3}-(25 \% \mathrm{x} \\
&\left.11.810 .418,88 \mathrm{~m}^{3}\right) \\
&=11.810 .418,88 \quad \mathrm{~m}^{3}- \\
& 2.952 .604,72 \mathrm{~m}^{3} \\
&=8.857 .814,16 \mathrm{~m}^{3} \\
& \text { Untuk SC }(\text { soil cover }) / \text { lapisan }
\end{aligned}
$$
tanah penutup dikalikan $15 \%$ dari 
volume total sampah (Murtudo, 1996) sebagai berikut:

$$
\begin{aligned}
\mathrm{SC} & =8.857 .814,16 \mathrm{~m}^{3} \times 15 \% \\
& =1.328 .672,12 \mathrm{~m}^{3}
\end{aligned}
$$

Pada prediksi lokasi TPA ini peniliti akan meproyeksikan TPA untuk pengoperasian hingga tahun 2026 sebesar:

$$
\begin{aligned}
& \mathrm{L}_{\mathrm{TPA}} \\
& =\frac{\mathrm{V}+\mathrm{SC}}{\mathrm{T}+\text { (penyusutan } \mathrm{x} \text { tahun } \mathrm{x} \text { prediksi) }} \\
& =\frac{8.857 .814,16 \mathrm{~m} 3+1.328 .672,12 \mathrm{~m} 3}{\mathrm{~T}+(0,002 \mathrm{~m} \times 365 \text { hari } \times 10 \text { tahun }} \\
& =\frac{8.857 .814,16 \mathrm{~m} 3+1.328 .672,12 \mathrm{~m} 3}{15 \mathrm{~m}+(0,002 \mathrm{~m} \times 365 \text { hari } \times 10} \\
& =\frac{10.186486,28 \mathrm{~m}^{3}}{23,3 \mathrm{~m}} \\
& =456.793,11 \mathrm{~m}^{2} \\
& =45,67 \mathrm{Ha} \\
& \begin{array}{c}
\text { Luas penyangg }=25 \% \times \text { Luas TPA } \\
=25 \% \times 45,67 \mathrm{Ha} \\
=11,42 \mathrm{Ha}
\end{array}
\end{aligned}
$$

Untuk perkiraan perencanaan penggunaan TPA yang melayani Kota Padang sampai tahun 2026 diperkirakan memerlukan lahan seluas 45,67 Ha dengan luas daerah penyangga seluas 11,42 Ha.

Setelah didapatkan hasil luas TPA dan zona penyangganya dilakukan analisis peta keseuaian lahan untuk TPA yang mengacu pada SNI 03-3241-1994. Penilaian dilakukan dengan metode binary untuk menentukan zona layak atau tidak layak sebagai lokasi TPA berdasarkan delapan kriteria penilaian kelayakan regional. Pada lahan yang memenuhi kriteria penilaian diberi nilai 1 dan lahan yang tidak memenuhi kriteria penilaian diberi nilai 0 . Sehingga zone layak TPA ditetapkan apabila nilai lahan mencapai jumlah maksimal (delapan).

Analisis SIG digunakan untuk mengevaluasi masing-masing kriteria penilaian tersebut secara spasial. Citra Landsat dan foto udara digunakan untuk interpretasi tutupan lahan. Peta Kemiringan Lereng, Peta Permeabilitas Tanah, Peta Kedalaman Muka Air Tanah dan Peta Bahaya Banjir diperoleh dari dinas Bappeda dan Prasjaltarkim Sumbar lalu dilaku proses pengharkatan. Proses buffering dilakukan pada Peta Geologi, Peta Hidrologi, Peta Administrasi, Peta Fungsi Kawasan sehingga diperoleh Peta Jarak Terhadap zona sesar aktif, Peta Jarak Terhadap Badan Air (Sungai), Peta Jarak Terhadap Batas Daerah, Peta Jarak Terhadap Permukiman, Peta Jarak Terhadap Kawasan Budidaya Pertanian, Peta Jarak Terhadap Kawasan Lindung, dan Peta Jarak Terhadap Lapangan Terbang. Sedangkan Peta Luas Lahan, Peta Ketersediaan Zona Penyangga dan Peta Intensitas Hujan diperoleh melalului proses calculating. Lokasi zone layak TPA diperoleh dari hasil overlay peta-peta tematik yang dihasilkan, sedangkan lokasi rekomendasi TPA diperoleh dari hasil overlay peta hasil penilaian dengan Peta Pola Ruang Kota Padang tahun 2010. 
Analisis kesesuaian lahan dilakukan di Kota Padang untuk penentuan TPA di Kota menghasilkan kesesuaian lahan Padang mempertimbangkan beberapa parameter kondisi fisik Kota Padang dengan metode pengharkatan sesuai dengan SNI 03-3241-1994 dengan penyesuaian penilaian tertinggi dengan nilai 3 dan bobot 5 pada parameter kriteria kelayakan penyisihan. Penelitiann yang

untuk zona layak TPA tersebar di beberapa kecamatan di Kota Padag, terutama pada Kecamatan Koto Tangah, Kecamatan Kuranji, dan Kecamatan Bungus Teluk Kabung Penentuan Zona Layak TPA dapat dilihat pada gambar berikut:

Gambar 2 : Peta Zona Layak TPA

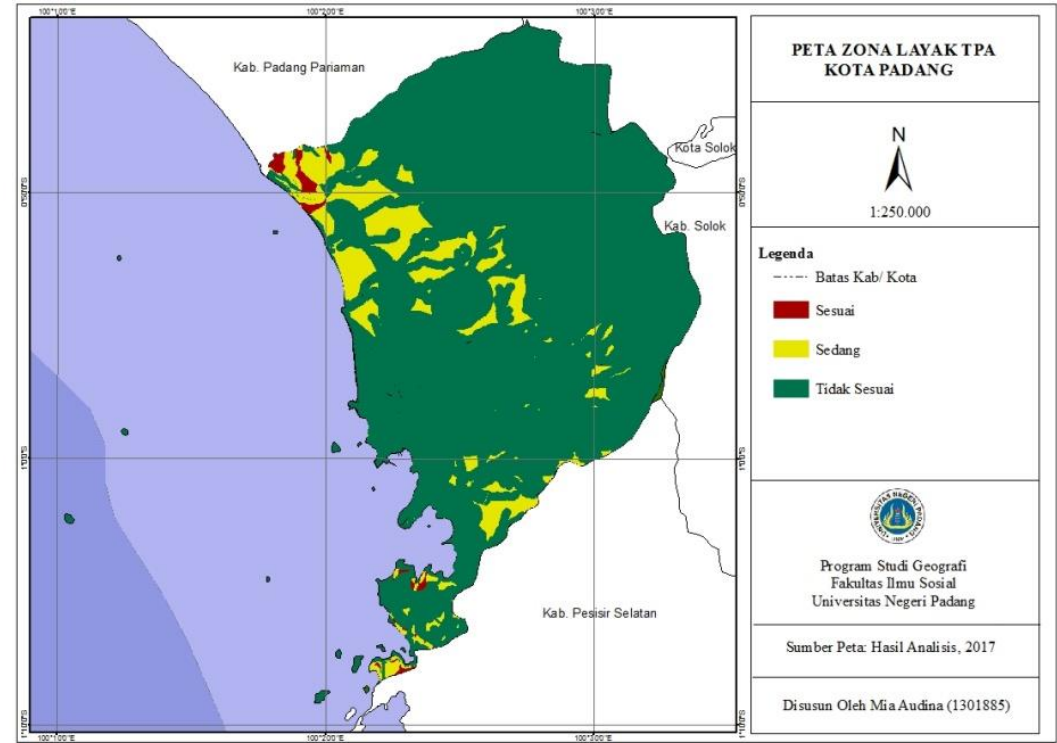

Sumber : Hasil Analisis dan Studi Literatur, 2017

Setelah didapatkan Peta Zona Layak TPA langkah selanjutnya adalah pemberian -pengharkatan terhadap peta fisik Kota Padang sesuai SNI 03-3241-1994 dan di overlay dengan Peta Zona Layak TPA Kota Padang untuk mendapatkan Peta Kelayakan Penyisihan TPA di Kota Padag. Hasil dari overlay tersebut lalu dikaitkan dengan akses jalan menuju daerah yang direkomendasikan sehingga pertimbangan utama rekomendasi adalah lokasi Kecamatan Koto Tangah dan Kecamatan Kuranji memiliki luas lahan yang cukup dalam pembangunan TPA dan memiliki akses yang baik. Selain itu dareah Kecamatan Koto Tangah dan Kecamatan Kuranji berada di luar zona sesar. Untuk kriteria permeabilitas tanah sebagian daerah rekomendasi memiliki tekstur tanah yang bersifat lempung. Umumnya batuan landasan adalah lempung atau pada dasar cekungan dilapisi geotekstil untuk menahan peresapan lindi pada tanah (Zaini, 2012). Daerah rekomendasi tersebut juga telah memenuhi beberapa kriteria yang ditentukan SNI 03-3241-1994 seperti jarak terhadap bandara, badan 
air, dan permukiman. Daerah yang dilihat pada gambar 3 dan 4 berikut: direkomendasikan tersebut dapat

Gambar 3 : Peta Kelayakan Penyisihan TPA

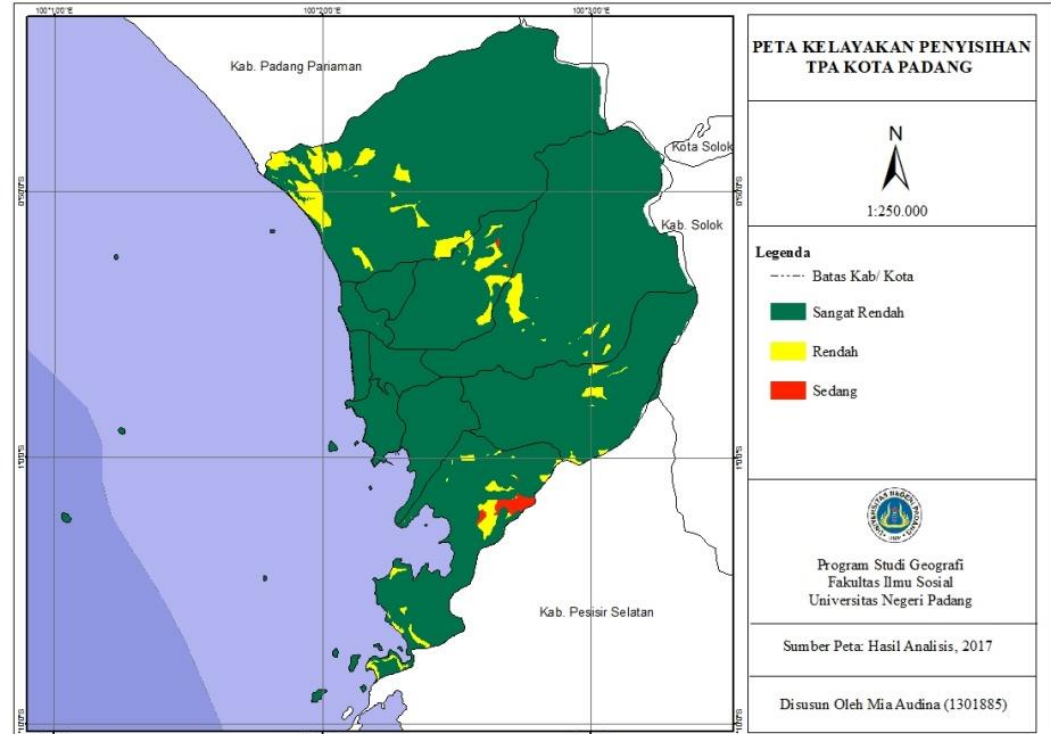

Sumber : Hasil Analisis dan Studi Literatur, 2017

Gambar 4 : Peta Rekomendasi Lokasi TPA

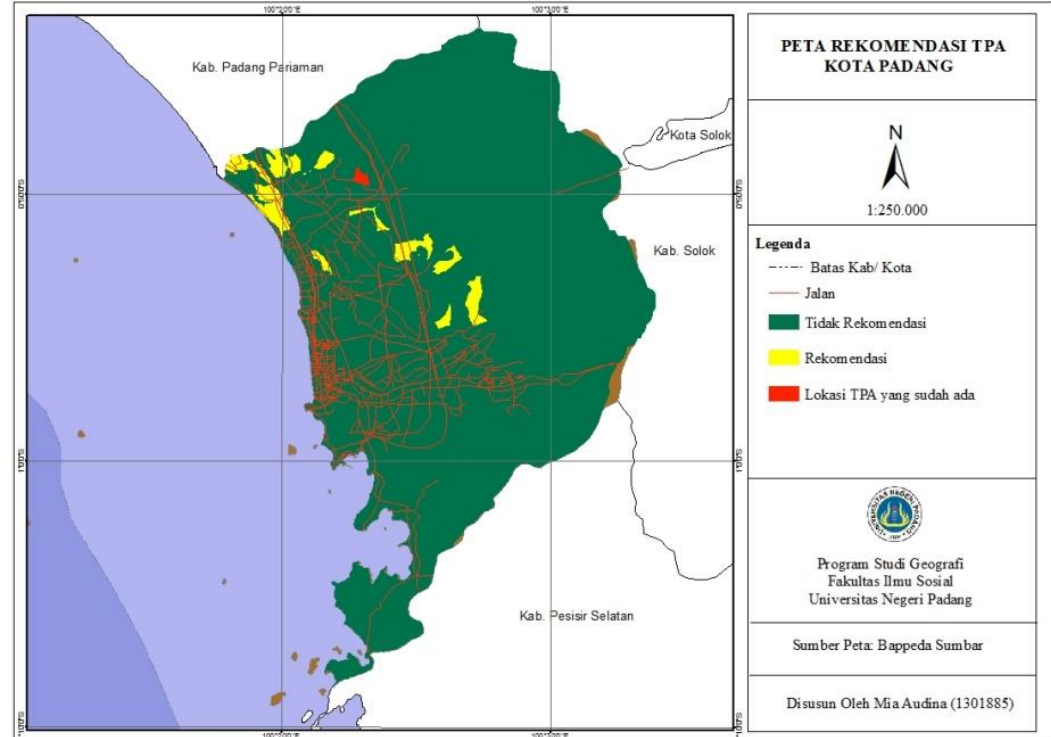

Sumber : Hasil Analisis dan Studi Literatur, 2017

Lahan diartikan sebagai lingkungan fisik yang terdiri atas iklim, relief, tanah, air, flora dan fauna, serta bentukan hasil budaya manusia. Dalam hal ini lahan juga mengandung pengertian ruang tempat (Arsyad, 1989). Luas lahan
TPA, kebutuhan tanah penutup dan zona penyangga dihitung dengan persamaan yang dirumuskan oleh Murtudo (1996). Penghitungan luas TPA didapatkan dari hasil volume sampah yang telah diapadatkan. Hasil pemadatan merujuk pada teori 
Nuryani, 2003 bahwa nilai yang digunakan dalam pemadatan sampah mempertimbangkan nilai yang mendekati kepadatan sampah di Kota jakarta. Hasil dari perhitungan tersebut adalah kebutuhan luas TPA di Kota Padang hinggga tahun 2026 sebesar 45,67 Ha dengan luas penyangga sebesar 11,42 Ha dengan sistem pengelolaan yang direkomendasikan adalah sanitary landfill untuk membawa pengaruh yang lebih positif terhadap pengelolaan TPA. Hal ini sejalan dengan teori Chandra Budiman bahwa pengelolaan sampah di suatu daerah akan membawa pengaruh bagi masyarakat maupun lingkungan daerah itu sendiri. Pengaruhnya tentu saja ada yang positif dan juga ada yang negatif (Chandra, 2006).

Hasil akhir penelitian ini adalah rekomendasi lokasi TPA yang diperoleh dari proses overlay Peta Kelayakan Regional dan Peta Kelayakan Penyisihan. Kategori kesesuaian lahan untuk pembangunan TPA sampah berada pada tingkat sedang, rendah, dan sangat rendah. Dari beberapa peta lahan untuk pembangunan TPA sampah lahan yang masih bisa diperhitungkan sebagai lokasi TPA sampah di Kota Padang berada pada kategori rendah dengan mengabaikan beberapa variable. Hal ini dilakukan mengingat tingkat kesesuaian yang tinggi atau yang diharapkan tidak tersedia. Apabila tidak ada lahan yang memungkinkan kembali pada
SNI 03-3241-1994 bahwa jika dalam suatu wilayah belum bisa memenuhi tahap regional, pemilihan TPA Sampah ditentukan berdasarkan skema pemilihan lokasi TPA Sampah. Dalam penilitian ini peneliti merekomendasikan pada Kecamatan Koto Tangah dan Kecamatan Kuranji.

\section{PENUTUP}

1. Kesimpulan

Berdasarkan hasil penelitian dan hasil pengolahan data diperoleh kesimpulan sebagai berikut:

a. Peneliti menganalisis 3 tutupan lahan dari Citra Landsat 7+TM Kota Padang tahun 2016. Adapun luas terbesar sampai ke yang terkecil berdasarkan hasil klasifikasi adalah sebagai berikut ; Vegetasi (51.486,40 Ha), Lahan Terbangun (11.578,44 Ha), dan Sawah $(5.713,93 \mathrm{Ha})$.

b. Prediksi jumlah penduduk Kota Padang pada tahun 2026 sebesar 1.011.116 jiwa. Dari hasil prediksi jumlah penduduk tersebut dapat dihitung besaran volume sampah yang dihasilkan hingga tahun 2026 sebesar $2.952 .604 .720 \mathrm{~kg} /$ jiwa.

c. Daya tampung lokasi yang digunakan untuk perkiraan perencanaan penggunaan TPA Kota Padang sampai tahun 2026 diperkirakan 
memerlukan lahan seluas 45,67 Ha dengan luas daerah penyangga seluas $11,42 \mathrm{Ha}$. Tingkat kesesuaian penyisihan TPA di Kota Padang berada pada tingkat sangat rendah, rendah, dan sedang. Daerah yang menjadi rekomendasi pembangunan TPA tersebar di wilayah Kecamatan Koto Tangah dan Kecamatan Kuranji. Pertimbangan pada daerah tersebut dikarenakan luas lahan kebutuhan TPA yang mencukupi dan memiliki akses transportasi yang cukup baik. Dareah Kecamatan Koto Tangah dan Kecamatan Kuranji berada di luar zona sesar. Untuk kriteria permeabilitas tanah sebagian daerah rekomendasi memiliki tekstur tanah yang bersifat lempung yang baik untuk pendirian TPA. Daerah rekomendasi tersebut juga telah memenuhi beberapa kriteria yang ditentukan SNI 03-3241-1994 seperti jarak terhadap bandara, badan air, dan permukiman.

\section{Saran}

Berdasarkan hasil penelitian dan kesimpulan yang telah penulis lakukan, maka penulis menyarankan sebagai berikut:

a. Bagi pemerintah agar memperhatikan dan memperbaiki pengelolaan
TPA Sampah di Kota Padang. TPA dengan pengelolaan open dumping cederung merusak dan memerlukan lahan yang banyak. AMDAL di lingkungan TPA juga perlu diperhatikan. Diperlukan pembinaan oleh pemerintah terhadap peran serta masyarakat terhadap pengelolaan sampah.

b. Bagi masyarakat agar lebih menjaga lingkungannya dengan tidak membuang sampah sembarangan. Peran serta masyarakat dapat dimulai dari skala individual rumah tangga yaitu dengan mereduksi timbulan sampah rumah tangga.

\section{DAFTAR PUSTAKA}

03-3241-1994, S. (t.thn.). tentang Tata Cara Pemilihan Lokasi TPA Sampah. Badan Standarisasi Nasional .

Akbar, P. F. (2016, 4 7). Daya Tampung TPA Air Dingin Tinggal 8 Tahun Lagi. Dipetik Februari 18, 2017, dari

https://www.katasumbar.com

Arsyad, S. (1989). Konservasi Tanah dan Air. Bogor: IPB Press.

Chandra, B. (2006). Pengantar Kesehatan Lingkungan. Jakarta: EGC. 
Junadi. (2008, Juni 10). Dipetik Juni 4, 2017, dari Model-Model Proyeksi Penduduk: https://www.google.co.id/am $\mathrm{p} / \mathrm{s} / \mathrm{junaidichaniago.cord}$

Lunkapis, G. J. (2004). GIS as Decision Support Tool for Landfills Siting, Journal of Urban Planning and Development.

Murtudo. (1996). Pengelolaan Limbah Padat dan Permasalahannya, Materi Pelatihan Pengelolaan Limbah Padat. Yogyakarta: PUSTEKLIM.

Rahman, D. (2014, Agustus 26). Dinas Kebersihan dan Pertamanan. Dipetik Maret 2, 2017, dari dkpkotapadang.blogspot.com

Rusdi, M. (2005). Perbandingan Klasifikasi Maximum Likelihood dan Object Oriented Pada Pemetaan Penutup/Penggunaan Lahan Studi Kasu Kabupaten Gayo Lues, NAD HTI PT Wirakarya Sakti Jambi dan Taman Nasional Lore Lindu
Sulawesi Tengah. Bogor: Institut Pertanian Bogor.

Sari, S. Y. (2013, September 11). Tempat Pembuangan Akhir (TPA) Air Dingin-Lubuk Minturun. Dipetik Desember 8, 2017, dari Laporan Kunjungan Lapangan Tempat Pembuangan Akhir (TPA) Air Dingin-Lubuk Minturun: https://shabrinayunitassari.blo gspot.co.id

Statistik, B. P. (2016). Padang dalam Angka 2016. Padang: BPS Kota Padang.

Tchobanoglous, G., Theisen, H., \& Vigil, S. (1993). Integrated Solid Waste Management. New York: McGraw-Hill.

Undang-Undang Republik Indonesia Nomor $18 \quad$ Tentang Pengelolaan Sampah. (2008). Jakarta.

Zaini, M. A. (2012, Juli 2). Pengelolaan Limbah Sampah (Open Dumping dan Controlled Landfill). Dipetik Januari 23, 2018, dari muhammad_agusfkm10.web.unair.ac.id 